"Rational, emotional and spiritual marketing strategies in Shariah banking in Medan, Indonesia"

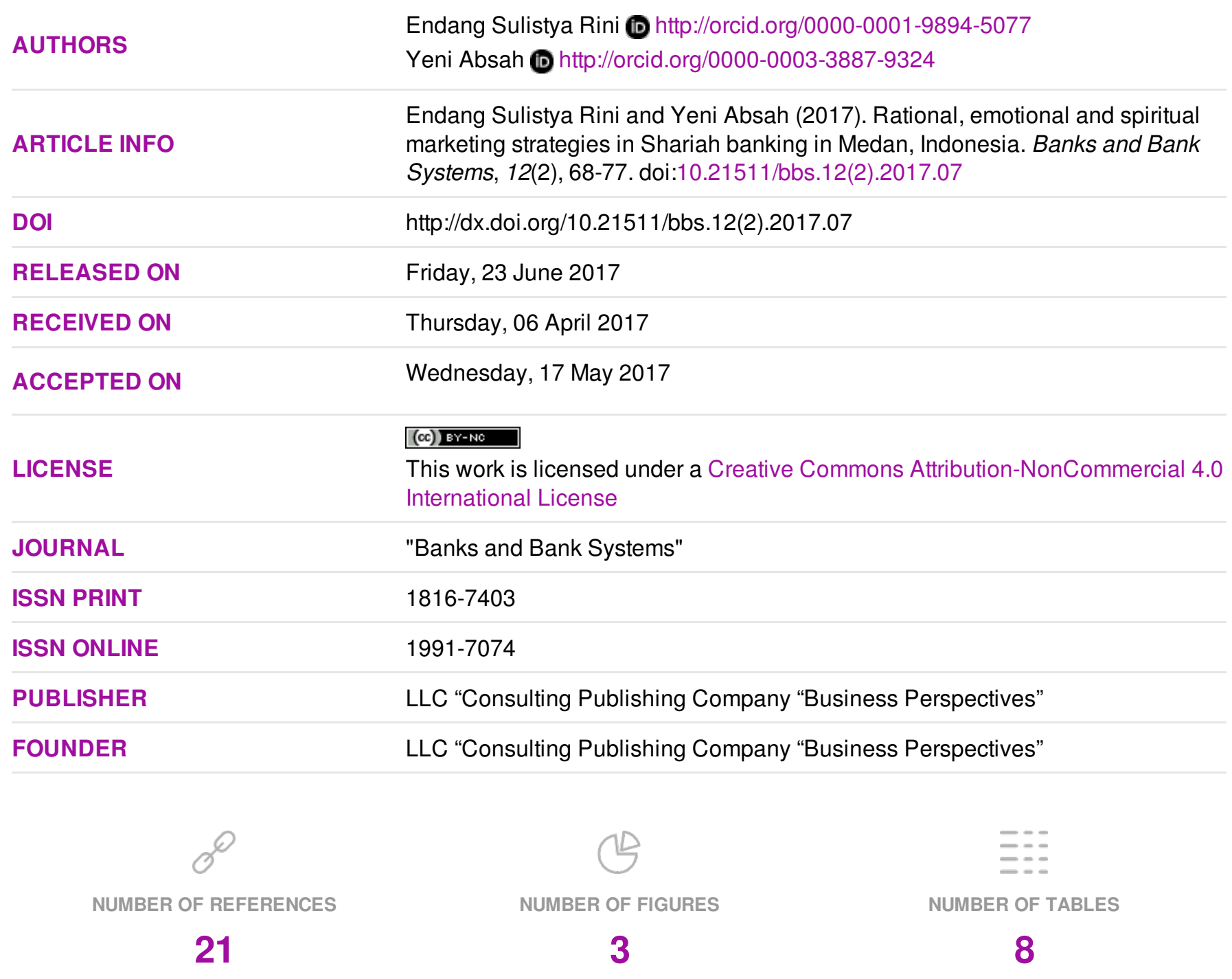

(C) The author(s) 2022. This publication is an open access article. 
Endang Sulistya Rini (Indonesia), Yeni Absah (Indonesia)

\title{
Rational, emotional and spiritual marketing strategies in Shariah banking in Medan, Indonesia
}

\begin{abstract}
This study was aimed to discover the direct influences of rational, emotional, and spiritual marketing on satisfaction, trust, and loyalty of Shariah banking customers in Medan. This study was an associative research, which is a research connecting two variables or more to see the influence of one variable on another. This study was conducted by means of an exploratory approach. The population in this study was Shariah banking customers in Medan. Total sample was 200 customers from 64 branches of Shariah banks across Medan. By using path analysis with SPSS 21 program, the results showed that there were direct and indirect influences of rational, emotional, and spiritual marketing on customer satisfaction, trust, and loyalty. Only emotional marketing variable had insignificant influence on the satisfaction of Shariah banking customers in Medan. This study was limited to impact of rational, emotional, spiritual marketing variables on satisfaction, trust, and loyalty of Shariah banking customers. Other variables which influence satisfaction, trust, and loyalty such as customer relationship management (CRM) and portfolio performance should be used, because they're factors which influence consumer behavior. For Shariah banking in Medan, the research result was expected to give useful suggestions and inputs for Shariah banking in Medan in implementing marketing strategies, especially rational, emotional, and spiritual.
\end{abstract}

Keywords: rational, emotional, spiritual marketing, customer satisfaction and trust and loyalty, Shariah banking.

JEL Classification: G21, M12, L84.

Received on: $6^{\text {th }}$ of April, 2016.

Accepted on: $17^{\text {th }}$ of May, 2017.

\section{Introduction}

The growth of Shariah banking in the past years was rapid, especially Shariah Commercial Banks (BUS) and Shariah Business Units (UUS), which dominate Shariah banking assets. In the data of Bank Indonesia (BI), the assets of Shariah banking per October 2013 raised to Rp 229,5 trillion year-over-year (yoy). Combined with the assets of Shariah People's Credit Bank (BPR), Shariah banking assets are Rp 235,1 trillion with \pm 12 million accounts or 9.2 percent of total national bank accounts, and total office network is 2,925 offices. The market share of Shariah banking in the map was \pm 4.8 percent per October 2013 (Rini and Absah, 2015). This market share was small. From time to time, it can be increased. To increase this market share, bank managers are encouraged to think creatively and innovatively to provide differentiation and advantages to products and services compared with the competitors. Shariah banking is necessary to not only develop good products, offer attractive prices, and make them available to customers, but also develop effective marketing strategies to create customer loyalty.

Kotler and Armstrong (2012) state that companies should design customer-oriented marketing strategies, so they should understand and satisfy customers' be-

\footnotetext{
(c) Endang Sulistya Rini, Yeni Absah, 2017.

Endang Sulistya Rini, Dr., Management Department, Faculty of Economics and Business, Universitas Sumatera Utara, Indonesia.

Yeni Absah, Management Department, Faculty of Economics and Business, Universitas Sumatera Utara, Indonesia.

This is an Open Access article, distributed under the terms of the Creative Commons Attribution-NonCommercial 4.0 International license, which permits re-use, distribution, and reproduction, provided the materials aren't used for commercial purposes and the original work is properly cited.
}

havior and needs to get customer loyalty. Loyal customers are valuable assets for companies. To create customers loalty, companies should make customers satisfied and trust the companies and their products or services. Consumer satisfaction is very important for companies, because it will impact sales performance. Kotler and Armstrong (2012) state that satisfied customers will repurchase and they will tell other people about the good experience with the products. Customer satisfaction contributes to several crucial aspects, such as the creation of customer loyalty. Another thing which creates customer loyalty is trust. Consumers who trust a company will have great confidence in the company, which eventually influences customer loyalty. In the marketing of services, which produce intangible products, the effectiveness depends on management, which is based on trust, because generally consumers purchase services based on confidence in parties which can be trusted (Rini and Absah, 2015).

Rini and Absah (2015) discover that satisfaction is influenced by rational, emotional, and spiritual marketing. The orientation of global technological development shifts from merely providing functional benefits (more productive, faster, more efficient, cheaper, etc.) to being devices which facilitate relaying emotional messages. Technology, particularly internet, isn't only able to create a physically different world (new economy), but also influences the attraction of new customers. Technology and communication advances have attracted customers who want the fulfillment of functional and emotional satisfactions when buying a product. In fact, emotional benefit tends to be more attractive than functional benefits. This tendency creates a new opportunity for companies with lower functional competitiveness to win competition by dif- 
ferentiating their products based on emotional value (Mussry et al., 2007). Therefore, aside from targeting customers' minds, it's more important to target customers' hearts by providing new experiences and sensations in consuming Shariah banking services.

Beside rational and emotional marketing strategies, companies should also apply a spiritual strategy. Although companies have used very sophisticated technology and had high quality employees, without credibility, companies will collapse. Marketing should also consider spirituality, which prioritizes universal love. The best marketing to market this noble value of the company is spiritual marketing. Spiritual marketing tries to help companies with good spirits in getting competitive advantages. In an era where business ethics is forgotten and honesty is a rare resource, spirituality in business is the next source of competitiveness. It also applies to Shariah banking business. Shariah banking is a banking system, which is implemented by Shariah. This system was created based on a prohibition in Islam to lend or collect debts by applying interests (riba), and prohibition to invest in forbidden or Haram businesses. Conventional and Shariah banking systems are similar in terms of seeking profit and community services in financial business. However, they're different in terms of distribution system for the customers. In conventional banking, distribution of fund is usually in the form of credits for the public where the debtors must pay some interest when returning the debts. Meanwhile, in Shariah banking, banking system isn't oriented to interest, but uses profit sharing system instead.

Shariah banking currently faces tight competition with conventional banks, and Shariah banks keep increasing in number. Many conventional banks expand their lines by opening banks based on Shariah. A total of Shariah bank offices in North Sumatra (Sumut) keeps increasing. As of January 2014, there were 115 Shariah bank units, which operate in Sumut. "In 2011 and 2012, there were 97 and 112 offices recorded, respectively. BI predicts that the number of Shariah bank offices still increases", said the Head of Region IX (Sumut-Aceh) Bank Indonesia Representative Office Hari Utomo in Medan (Rini and Absah, 2015). A total of Shariah bank offices in Medan was 84 units. Loyal customers are important assets for companies. To get loyal customers, companies should provide satisfaction and trust for all customers. Sastisfaction and trust can be built by effective marketing strategies by rational, emotional, and spiritual marketing strategies. However, current marketing strategies of Shariah banking aren't maximum. This is shown by the low market share of Shariah banking, which is $4.89 \%$. Healthy banking is a banking which is able to get high profit. With the profit, banks can improve the welfare of the employees, open job opportunities, and increase government revenue through tax. Beside facing tight competition, Shariah banking also faces another problem. People's perception on nonShariah banking or conventional banking is that it's more financially profitable than Shariah banking because of its interest system. The profit sharing system applied by Shariah banks is considered identical to interest in conventional banks. Another problem is people's lack of knowledge on Shariah banking system. A lot of people think Shariah banks are only for Muslims and doubt the Shariah principles applied there. The formulation of the problem of this study was whether there's any direct and indirect influence of rational, emotional, and spiritual marketing on the satisfaction of Shariah banking customers in Medan.

\section{Literature review}

1.1. Rational marketing. Rational marketing is more often called conventional marketing. Usually someone buys based on logical or rational considerations. People rationally want, are interested in, and buy the offered products or services. Rational level is characterized by the usage of smart marketing tools, such as marketing mix, branding and positioning. A company uses rational marketing if (Dewanti et al., 2016):

1. The company can produce products with optimal usage for consumers.

2. The products are really needed by consumers.

3. Quality of products is guaranteed.

4. Affordable prices are based on consumers' welfare.

1.2. Emotional marketing. Generally, emotional marketing will work well if a company can prioritize experience satisfaction in using products or services. Products and services create emotional relations with the people served. The challenge is to identify how products/services can be related to emotions. Emotional marketing can only happen after giving customers experiences, which realize the core benefits. According to Kartajaya (2003) and Livingstone (2016), many emotional contents brought by information technology advances have influenced customers to be more emotional. Information technology enables someone to reveal and express his/her emotions quickly, easily and practically, without waiting for too long. Human's natural needs to express emotions and feelings - sadness, happiness, awe, admiration, love, longing, amazement to someone, empathy, satisfaction - can be relieved by a few clicks of a computer mouse or a few presses of cell phone buttons. Feeling is the root of many things influencing all behaviors, because feelings are related to emotions. Emotion strongly influences one's thoughts (Zachra, 2011). Emotion shapes and influences the 
assessment, and it forms behaviors. Therefore, companies should pay attention to customers' emotions and try to influence customers so that they have positive emotions. It's expected that with this, their thoughts and behaviors on the companies, products and services offered also become positive.

1.3. Spiritual marketing. Spiritual marketing is an ethical and honest marketing, which maximizes the satisfaction of stakeholders in a balanced way. These values are believed to not only increase the profit, but also guarantee the survival and strengthening of brand characters while forming incomparable differentiation. Rational, emotional, and spiritual marketing strategies can be synergized and combined to produce more optimal marketing and provide more positive benefits for consumers or customers (Rini and Absah, 2015). Usually, one purchases based on logical or rational consideration and if people rationally want, are interested in, and buy products or services, then, companies should also be able to provide something which touches the customers' emotion. After giving the best to the consumer, both rationally and emotionally, a synergy of rational, emotional and spiritual marketing can be created (Livingstone, 2016). In spiritual marketing, a consumer will consider what to decide, buy or use which can also give meanings for his/her afterlife. Therefore, a businessperson should also develop this spiritual marketing.

1.4. Customer satisfaction. Satisfaction is a feeling where one states the result of a comparison between the performances of a product (service) received and expected. Satisfaction is one's happiness or disappointment after comparing his/her perception/impression on the performance of a product and his/her expectations. Customer satisfaction is experienced after consumers make post-purchase evaluation, where the perception on the alternative performance of a selected product/service meets or exceeds the expectations before the purchase (Kotler and Keller, 2009). Similarly, Zeithaml et al. (1990), Cumming and Leveridge (1996), Peppers and Rogers (2004) and DeWitt et al. (2008) state customer satisfaction is a response to evaluation of imbalance between initial expectations and actual performance of products which is experienced after usage. Meanwhile, Tjiptono (2004) states that customer satisfaction is determined by two things, such as customer complaints and expectations on services received. Customer satisfaction in service industry is a function of difference between the appearances experienced and expected. There are 3 (three) levels of satisfaction, which are: 1) if appearance is less than expectation, customers are dissatisfied; 2) if appearance is equal to expectation, customers are satisfied; 3 ) if appearance exceeds expectation, customers are very satisfied or happy. According to
Parasuraman et al. (1990), there are five gaps which cause failure in delivering services:

1. Gap between consumer expectation and management perception, which is the gap between consumer satisfaction and customer perception, which emerge, because the management doesn't always fully know what the consumers want.

2. Gap between management perception and service quality specification, which is the gap between management perception and service quality. Maybe the management knows what the consumers want, but the management can't or don't fully provide the consumer desire. Essentially, the management doesn't pay enough attention to the details of the offered service.

3. Gap between service quality specifications and service delivery, which is the gap between service quality and service delivery. The keyword is that management can't deliver the service satisfactorily to consumers.

4. Gap between service delivery and external communications, which is the gap between service delivery and external communication due to promises in testimonies, advertisements, brochures, etc. The keyword is that advertisements and other promotions are too much and don't match the reality.

5. Gap between perceived service and expected service, which is the gap between received service and expected service.

1.5. Trust. Trust is a belief that one will find what $\mathrm{s} /$ he wants in an exchange partner. Trust involves someone's willingness to act in a certain way due to belief that the partner will give what s/he expects and an expectation generally held by someone that someone else's words, promises, or statements can be trusted (Barnes, 2003). Green (in Pepers and Rogers, 2004) states that the components of trust are:

- Credibility. Credibility means that employees are honest and their words can be trusted. Credibility should be shown in words. "I can trust what s/he says about..." Other related forms are believability and truthfulness.

- Reliability. Reliability means something is reliable or dependable. It means it's related to the quality of an individual/organization. Reliability should be shown in action. "I can trust what s/he does ..." Other related forms are predictability and familiarity.

- Intimacy. A related word is integrity, which means employees have the quality as employees with strong moral principles. Integrity shows internal consistency, which is consistency between words and actions, thoughts and actions. Furthermore, integrity shows earnestness. 
1.6. Loyalty. Kotler and Keller (2009) state that customer loyalty is the customers' commitment to a brand and supplier based on positive attitudes and reflected in consistent purchases. Griffin (2002) states that the characteristics of loyal customers are:

- Making regular purchases.

- Purchasing outside of product/service lines.

- Recommending it to other people.

- Showing insusceptibility to the attractiveness of similar products from competitors.

Customer loyalty is an attitude, which drives the customers to purchase products/services from a company, which includes emotional aspect, especially purchasing regularly and repeatedly with high consistency, not only purchasing a product or service, but also having commitment and positive attitude to the company, which offers the product/service.

\section{Previous researches}

Rini and Absah (2015) conducted a study titled "Pengaruh Penerapan Strategi Pemasaran Rasional, Emosional, dan Spiritual terhadap Kepuasan dan Loylitas Nasabah PT.Bank Sumut Shariah Cabang Utama Medan". The population in this study was 8257 customers of Medan main branch of Bank Sumut Shariah, with a total sample of 100 people. Respondents were determined by systematic random sampling. The data analysis techniques used were Descriptive analysis and path analysis. The research result shows that rational, emotional, and spiritual marketing simultaneously have positive and significant influence the satisfaction of customers of Medan branch of Bank Sumut Shariah. The result of $t$ test showed that emotional and spiritual marketing had a positive and significant influence on the satisfaction of the customers of Bank Sumut Shariah, customer satisfaction had a positive and significant influence on the loyalty of the customers of Medan branch of Bank Sumut Shariah. Meanwhile, rational marketing had an insignificant influence on the satisfaction of customers Medan branch of Bank Sumut Shariah.

\section{Conceptual framework}

Waringin (2012) states that usually one purchases based on logical or rational consideration and if people rationally want, are interested in, and buy products or services, then, companies should also be able to provide something, which touches the customers' emotion. This is so that the purchase continues, not only in a short term. This can be done by creating closeness, giving attention earnestly and regularly. Beside the consumers, companies can also give their attention to people around them who have special closeness or meaning for the consumers (e.g., children, partners, parents, etc.) so that the customers feel cared for and appreciated. Generally, rational and emotional marketing, which are performed well, will be able to create customer satisfaction in using company products or services. Moreover, rational and emotional marketing can also influence trust. Kotler and Keller (2009) defines trust as an overview of one's thoughts on something. Trust based on knowledge, opinion, and belief can be influenced by rational and emotional factors.

Another factor which drives people to become bank customers is a spiritual factor. Spiritual marketing is a marketing instilled with religious spiritual values in every process and transaction. Spiritual marketing contains worship values based on the most basic needs such as honesty, moral and ethics in business and, therefore, can influence customer trust. In spiritual marketing, a consumer will consider what to decide, purchase, or use to also give meanings to his/her afterlife. The implementation of rational, emotional and spiritual marketing strategies is predicted to create customer satisfaction and trust and finally make customers loyal. Griffin (2002) argues that loyal customers are customers who are very satisfied with certain products or services so they enthusiastically introduce them to anyone they know. Based on the background and description above, the conceptual framework is as follows:

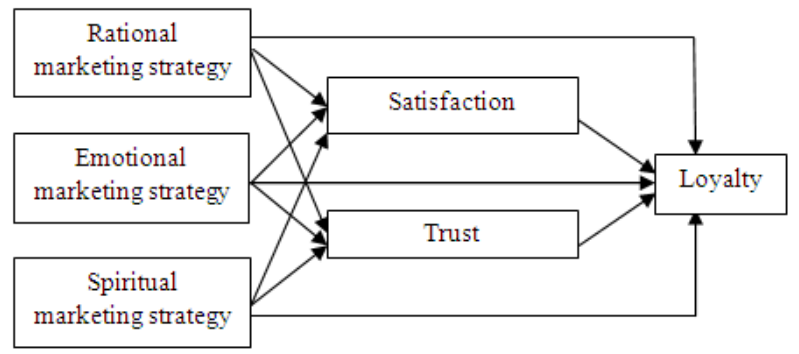

Fig. 1. Conceptual framework

\section{Hypothesis}

There are direct and indirect influences of rational, emotional and spiritual marketing on the satisfaction of Shariah banking customers in Medan.

\section{Research method}

5.1. Research type. This study was an associative research, which is a research, which connects two variables or more to see the influence of one variable on another (Lutfi et al., 2016; Dalimunthe et al., 2016; Muda et al., 2016). The explanatory survey approach is used for testing a series of relationships between independent variables and a dependent variable with hypothesis proofing. In addition, a combination of quantitative and qualitative research is used in this study.

5.2. Operational definition. The operational definitions of the research variables are: 
Table 1. Variable operationalization

\begin{tabular}{|c|c|c|c|}
\hline Variable & Definition & Indicator & Scale \\
\hline $\begin{array}{l}\text { Rational marketing } \\
\left(\mathrm{X}_{1}\right)\end{array}$ & $\begin{array}{l}\text { Rational marketing is a marketing strategy designed based on } \\
\text { consumer motivation in choosing products due to rational reasons }\end{array}$ & $\begin{array}{ll}\text { 1. } & \text { Benefit } \\
\text { 2. } & \text { Service quality } \\
\text { 3. } & \text { Product quality } \\
\text { 4. } & \text { Ease of access }\end{array}$ & Likert \\
\hline $\begin{array}{l}\text { Emotional marketing } \\
\left(\mathrm{X}_{2}\right)\end{array}$ & $\begin{array}{l}\text { Emotional marketing is a marketing strategy designed based on } \\
\text { consumers' desire to buy to express their emotions and feelings }\end{array}$ & \begin{tabular}{|ll} 
1. & Closeness \\
2. & Comfort \\
3. & Security
\end{tabular} & Likert \\
\hline $\begin{array}{l}\text { Spiritual marketing } \\
\left(X_{3}\right)\end{array}$ & $\begin{array}{l}\text { Spiritual marketing is a marketing strategy designed based on } \\
\text { ethics and honesty }\end{array}$ & $\begin{array}{l}\text { 1. Based on Islamic Shariah } \\
\text { 2. Avoiding riba system } \\
\text { 3. Honesty }\end{array}$ & Likert \\
\hline $\begin{array}{l}\text { Customer satisfaction } \\
\left(Y_{1}\right)\end{array}$ & $\begin{array}{l}\text { Customer/consumer satisfaction is one's happi- } \\
\text { ness/disappointment from the comparison between the impression } \\
\text { on the performance (result) of a product and the expectations }\end{array}$ & $\begin{array}{ll}\text { 1. } & \text { Service meeting expectations } \\
\text { 2. } & \text { Profit sharing system meeting expectations } \\
\text { 3. } & \text { Implemented Shariah meeting expectations }\end{array}$ & Likert \\
\hline Customer trust $\left(\mathrm{Y}_{2}\right)$ & $\begin{array}{l}\text { Customer's belief that the bank can be relied on and has high } \\
\text { integrity }\end{array}$ & $\begin{array}{ll}\text { 1. } & \text { Reliable bank staff } \\
\text { 2. } & \text { Reliable bank } \\
\text { 3. } & \text { High integrity bank }\end{array}$ & Likert \\
\hline Customer loyalty & $\begin{array}{l}\text { Strong commitment to keep being a customer and have positive } \\
\text { attitude toward Bank Sumut Shariah }\end{array}$ & $\begin{array}{ll}\text { 1. } & \text { Continues to be a customer } \\
\text { 2. } & \text { Buying outside the line of products / services } \\
\text { 3. } & \text { Refer to others } \\
\text { 4. } & \text { Shows immune to the charms of similar products from competitors }\end{array}$ & Likert \\
\hline
\end{tabular}

Source: Kartajaya (2004), Mussry et al. (2007) and Setiadi (2003).

5.3. Research population and sample. The population in this study was Shariah banking customers in Medan from Bank Muammalat, Bank Negara Indonesia (BNI) Shariah and Bank Mandiri Shariah. Total sample by SEM analysis was $10 \mathrm{x}$ total indicator. Total indicator in this study was 20 , so total sample was $10 \times 20=200$ customers in 64 branches of Shariah banks across Medan. Respondents were determined by systematic random sampling, where sampled customers were every three customers who came one after another and then two customers later.

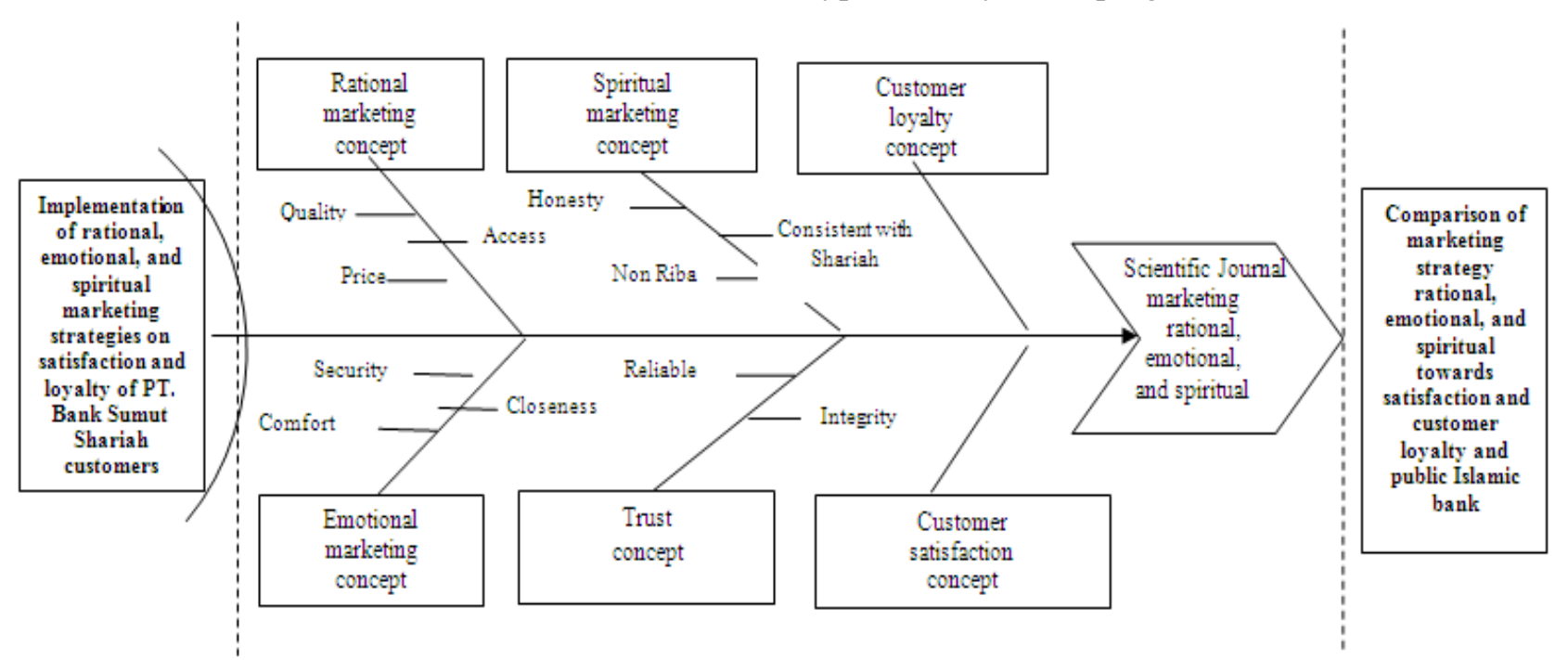

Fig. 2. Research flowchart
5.4. Data type. The data in this study were primary data, which are the data directly collected from selected respondents in the research location. Primary data were collected by giving a list of questions (Muda and Dharsuky, 2015). The questionnaire consisted of two parts. The first section contains a number of questions of a general nature, namely the demographic data of respondents.

5.5. Data analysis technique. The technique used was descriptive statistical analysis and inferential statistical analysis by path analysis to test research hypothesis by SPSS program. 


\section{Research result and discussion}

6.1. Descriptive statistics. The respondents of this study are described in Table 2.

Table 2. Research respondents

\begin{tabular}{|l|c|c|}
\hline \multicolumn{1}{|c|}{ Gender } & Total & $\%$ \\
\hline Male & 102 & 51 \\
\hline Female & 98 & 49 \\
\hline Total & 200 & 100 \\
\hline
\end{tabular}

\begin{tabular}{|l|c|c|}
\hline \multicolumn{3}{|c|}{ Age group } \\
\hline $20-30$ years-old & 64 & 32 \\
\hline $31-40$ years-old & 81 & 40.5 \\
\hline $41-50$ years-old & 39 & 19.5 \\
\hline $51-55$ years-old & 16 & 0.08 \\
\hline Total & 200 & 100 \\
\hline
\end{tabular}

\begin{tabular}{|l|c|c|}
\hline \multicolumn{3}{|c|}{ Occupation } \\
\hline Civil servant & 18 & 9.0 \\
\hline Private employee & 22 & 11.0 \\
\hline
\end{tabular}

\begin{tabular}{|l|c|c|}
\hline Entrepreneur & 20 & 10.0 \\
\hline Housewife & 7 & 3.5 \\
\hline Student & 104 & 52.0 \\
\hline Others & 29 & 14.5 \\
\hline Total & 200 & 100.0 \\
\hline
\end{tabular}

\begin{tabular}{|l|c|c|}
\hline \multicolumn{3}{|c|}{ Religion } \\
\hline Buddhism & 1 & 0.5 \\
\hline Islam & 187 & 93.5 \\
\hline Christian & 12 & 6.0 \\
\hline Total & 200 & 100.0 \\
\hline \multicolumn{3}{|c|}{ Length of being a customer } \\
\hline $1-3$ Years & 103 & 51.5 \\
\hline $3.1-5$ Years & 72 & 36 \\
\hline$>5$ Years & 25 & 12.5 \\
\hline Total & 200 & 100.0 \\
\hline
\end{tabular}

Source: tabulation result (2015).

6.2. Research result. 6.2.1. Result of hypothesis test. The result of simultaneous testing is shown in Table 3.

Table 3. Result of simultaneous testing by path analysis

\begin{tabular}{|c|l|c|c|}
\hline No. & \multicolumn{1}{|c|}{ Description } & F count & Sig. value \\
\hline 1 & $\begin{array}{l}\text { The influence of rational, emotional, and } \\
\text { spiritual marketing on customer satisfaction }\end{array}$ & 50.594 & 0.000 \\
\hline 2 & $\begin{array}{l}\text { The influence of rational, emotional, and } \\
\text { spiritual marketing on customer trust }\end{array}$ & 33.224 & 0.000 \\
\hline 3 & $\begin{array}{l}\text { The influence of rational, emotional, and } \\
\text { spirtual marketing on customer loyalty }\end{array}$ & 27.574 & 0.000 \\
\hline 4 & $\begin{array}{l}\text { The influence of satisfaction and trust on } \\
\text { customer loyalty }\end{array}$ & 40.065 & 0.000 \\
\hline
\end{tabular}

Source: result processed by SPSS 21 (2015).

Table 3 shows that rational, emotional, and spiritual marketing stategies simultaneously had a positive and significant influence on the satisfaction of Shariah banks customers in Medan. This is shown by significant value $0.000<0.05$ or $F_{\text {count }}(50.594)>F_{\text {table }}(2.75)$. Rational, emotional, and spiritual marketing strategies had a positive and significant influence on the trust of Shariah bank customers in Medan. This is shown by significant value $0.000<0.05$ or $F_{\text {coun }}(33.224)>$
$F_{\text {table }}(2.75)$. Rational, emotional, and spiritual marketing strategies had a positive and significant influence on the loyalty of Shariah bank customers. This is shown by significant value $0.000<0.05$ or $F_{\text {count }}(27.574)>F_{\text {table }}(2.75)$. Satisfaction and trust simultaneously had a positive and significant influence on customer loyalty. This is shown by significant value $0.000<0.05$ or $F_{\text {coun }}(40.065)>F_{\text {table }}(2.75)$. The result of determination test is shown in Table 4.

Table 4. Result of determination test of path analysis

\begin{tabular}{|c|l|c|}
\hline No. & \multicolumn{1}{|c|}{ Description } & $\mathrm{R}^{2}$ value \\
\hline 1 & $\begin{array}{l}\text { The influence of rational, emotional, and spiritual } \\
\text { marketing on customer satisfaction }\end{array}$ & 0.436 \\
\hline 2 & $\begin{array}{l}\text { The influence of rational, emotional, and spiritual } \\
\text { marketing on customer trust }\end{array}$ & 0.327 \\
\hline 3 & $\begin{array}{l}\text { The influence of rational, emotional, and spiritual } \\
\text { marketing on customer loyalty }\end{array}$ & 0.297 \\
\hline 4 & The influence of satisfaction and trust on customer loyalty & 0.282 \\
\hline
\end{tabular}

Source: result processed by SPSS 21 (2015).

Table 4 shows that $\mathrm{R}^{2}$ for the influence of rational, emotional, and spiritual marketing on customer satisfaction is 0.436 , meaning simultaneously, the three independent variables can explain 0.436 customer satisfaction while the remaining 0.564 is explained by other variables. Rational, emotional, and spiritual marketing strategies can explain 0.327 customer trust and the remaining 0.673 is explained by other variables. Rational, emotional, and spiritual marketing strategies can explain 0.297 customer loyalty and the remaining 0.703 is explained by other variables. Satisfaction and trust can explain 0.282 customer loyalty and the remaining 0.712 is explained by other variables.

Table 5. Partial test of the first equation

\begin{tabular}{|l|l|c|c|c|c|c|}
\hline \multicolumn{2}{|c|}{ Model } & \multicolumn{2}{|c|}{$\begin{array}{c}\text { Unstandardized } \\
\text { coefficients }\end{array}$} & $\begin{array}{c}\text { Standardized } \\
\text { coefficients }\end{array}$ & \multirow{2}{*}{$t$} & \multirow{2}{*}{ Sig. } \\
\cline { 3 - 7 } \multicolumn{2}{|c|}{} & B & Std. error & Beta & & \\
\hline \multirow{3}{*}{1} & (Constant) & 2.165 & 1.417 & & 1.528 & .128 \\
\cline { 2 - 7 } & P_Rational & .235 & .074 & .221 & 3.177 & .002 \\
\cline { 2 - 7 } & P_Emotional & .029 & .187 & .120 & 0.155 & .063 \\
\cline { 2 - 7 } & P_Spiritual & .395 & .078 & .343 & 5.093 & .000 \\
\hline \multicolumn{2}{|l|}{ a. Dependent variable: satisfaction } \\
\hline
\end{tabular}

Source: result processed by SPSS 21 (2015).

The first equation of path analysis is:

$Y_{1}=0,221 X_{1}+0,120 X_{2}+0,343 X_{3}+\epsilon_{1}$.

Table 5 shows that:

- Rational marketing varible had positive and significant influence on customer satisfaction. It's shown by significant value (0.002), which is smaller than $5 \%$ and $t_{\text {count }}(3.177)>t_{\text {table }}(1.980)$. It means if rational marketing strategy was increased, the satisfaction of Shariah bank customers would increase.

- Emotional marketing variable had a positive and insignificant influence on customer satisfaction. It's shown by significant value $(0.063)$ which is 
bigger than $5 \%$ and $t_{\text {count }}(0.155)<t_{\text {table }}(1.980)$. It means even if emotional marketing was increased, the satisfaction of Shariah bank customers wouldn't increase.

- Based on significant value (0.002), which is smaller than $5 \%$ and $t_{\text {count }}(3.177)>t_{\text {table }}(1.980)$, it's discovered that spiritual marketing variable had a positive and significant influence on the satisfaction of Shariah bank customers. It means if spritual marketing strategy was increased, the satisfaction of Shariah bank customers would increase.

Table 6. Partial test ( $t$-test) of the second equation

\begin{tabular}{|l|l|c|c|c|c|c|}
\hline \multirow{2}{*}{\multicolumn{2}{|c|}{ Model }} & \multicolumn{2}{|}{$\begin{array}{c}\text { Unstandardized } \\
\text { coefficients }\end{array}$} & $\begin{array}{c}\text { Standardized } \\
\text { coefficients }\end{array}$ & \multirow{2}{*}{$t$} & \multirow{2}{*}{ Sig. } \\
\cline { 3 - 7 } & B & Std. error & Beta & & \\
\hline \multirow{3}{*}{1} & (Constant) & 4.153 & 1.227 & & 3.385 & .001 \\
\cline { 2 - 7 } & P_Rational & .195 & .064 & .230 & 3.052 & .003 \\
\cline { 2 - 7 } & P_Emotional & .182 & .066 & .219 & 2.745 & .007 \\
\cline { 2 - 7 } & P_Spiritual & .222 & .067 & .241 & 3.307 & .001 \\
\hline \multicolumn{2}{|l|}{ a. Dependent variable: trust } \\
\hline
\end{tabular}

Source: result processed by SPSS 21 (2015).

In Table 6, the second equation of path analysis is:

$Y_{2}=0,064 X_{1}+0,066 X_{2}+0,067 X_{3}+\epsilon_{2}$.

Table 6 shows that:

- Rational marketing variable had a positive and significant influence on customer trust. It's shown by significant value $(0.003)$, which is smaller than $5 \%$ and $t_{\text {count }}(3.052)>t_{\text {table }}(1.980)$. It means if rational marketing strategy was increased, the trust of Shariah bank customers would increase.

- Emotional marketing variable had a positive and significant influence on customer trust. It's shown by significant value $(0.007)$ which is smaller than $5 \%$ and $t_{\text {count }}(2.745)<t_{\text {table }}(1.980)$. It means if emotional marketing strategy was increased, the trust of Shariah bank customers would increase.

- Based on significant value (0.001) which is smaller than $5 \%$ and $t_{\text {coun }}(3.307)>t_{\text {tabel }}(1.980)$, it's discovered that spiritual marketing variable had a positive and significant influence on the satisfaction of Shariah bank customers. It means if spritual marketing strategy was increased, the satisfaction of Shariah bank customers would increase.

Table 7. Partial test ( $t$-test) of the third equation

\begin{tabular}{|l|l|c|c|c|c|c|}
\hline \multirow{2}{*}{ Model } & \multicolumn{2}{|c|}{$\begin{array}{c}\text { Unstandardized } \\
\text { coefficients }\end{array}$} & $\begin{array}{c}\text { Standardized } \\
\text { coefficients }\end{array}$ & \multirow{2}{*}{$t$} & \multirow{2}{*}{ Sig. } \\
\cline { 3 - 5 } & B & Std. error & Beta & & \\
\hline \multirow{3}{*}{1} & (Constant) & 2.251 & 1.467 & & 1.534 & .127 \\
\cline { 2 - 7 } & P_Rational & .173 & .076 & .176 & 2.263 & .025 \\
\cline { 2 - 7 } & P_Emotional & .203 & .079 & .210 & 2.557 & .011 \\
\cline { 2 - 6 } & P_Spiritual & .278 & .080 & .261 & 3.468 & .001 \\
\hline
\end{tabular}

Source: result processed by SPSS 21 (2015).
The third equation of path analysis is:

$Y_{1}=0,176 X_{1}+0,210 X_{2}+0,261 X_{3}+\epsilon_{3}$.

Table 7 shows that:

- Rational marketing variable had a positive and significant influence on customer loyalty. It's shown by significant value $(0.025)$, which is smaller than $5 \%$ and $t_{\text {count }}(2.263)>t_{\text {table }}(1.980)$. It means if rational marketing strategy was increased, the satisfaction of Shariah bank customers would increase.

- Emotional marketing variable had a positive and significant influence on customer loyalty. It's shown by significant value $(0.011)$, which is bigger than $5 \%$ and $t_{\text {count }}(2.557)<t_{\text {table }}(1.980)$. It means if emotional marketing strategy was increased, the trust of Shariah bank customers would increase.

- Based on significant value $(0,001)$, which is smaller than $5 \%$ and $t_{\text {count }}(3.468)>t_{\text {table }}(1.980)$, it's discovered that spiritual marketing variable had a positive and significant influence on the satisfaction of Shariah bank customers. It means if spritual marketing strategy was increased, the satisfaction of Shariah bank customers would increase.

Table 8. Partial test ( $t$-test) of the fourth equation

\begin{tabular}{|l|l|c|c|c|c|c|}
\hline \multicolumn{2}{|c|}{ Model } & \multicolumn{2}{|c|}{$\begin{array}{c}\text { Unstandardized } \\
\text { coefficients }\end{array}$} & $\begin{array}{c}\text { Standardized } \\
\text { coefficients }\end{array}$ & \multirow{2}{*}{$t$} & \multirow{2}{*}{ Sig. } \\
\cline { 3 - 7 } \multicolumn{2}{|c|}{1} & B & Std. error & Beta & & \\
\hline \multirow{2}{*}{1} & (Constant) & 4.384 & 1.252 & & 3.502 & .001 \\
\cline { 2 - 7 } & Satisfaction & .208 & .070 & .224 & 2.986 & .003 \\
\cline { 2 - 7 } & Trust & .433 & .087 & .373 & 4.967 & .000 \\
\hline \multicolumn{2}{|l|}{ a. Dependent variable: loyalty } \\
\hline
\end{tabular}

Source: result processed by SPSS 21 (2015).

The fourth equation of path analysis is:

$Y_{1}=0,070 X_{1}+0,087 X_{2}+\epsilon_{4}$.

Table 8 shows that:

- Satisfaction variable had a positive and significant influence on customer loyalty. It's shown by significant value (0.003), which is smaller than $5 \%$ and $t_{\text {count }}(2.986)>t_{\text {table }}(1.980)$. It means if customer satisfaction increased, the loyalty of Shariah bank customers would increase.

- Trust variable had a positive and significant influence on customer loyalty. It's shown by significant value $(0.000)$ which is bigger than $5 \%$ and $t_{\text {count }}(4.967)>t_{\text {table }}(1.980)$. It means if customer trust increased, the loyalty of Shariah bank customers would increase.

Indirect influences (indirect effects or IE) in path equation models are as follows:

- The influence of rational marketing variable on customer loyalty through customer satisfaction IE: $\mathrm{X} 1 \rightarrow \mathrm{Y} 1 \rightarrow \mathrm{Y} 3=(0.221 \times 0.070)=0.01547$ 


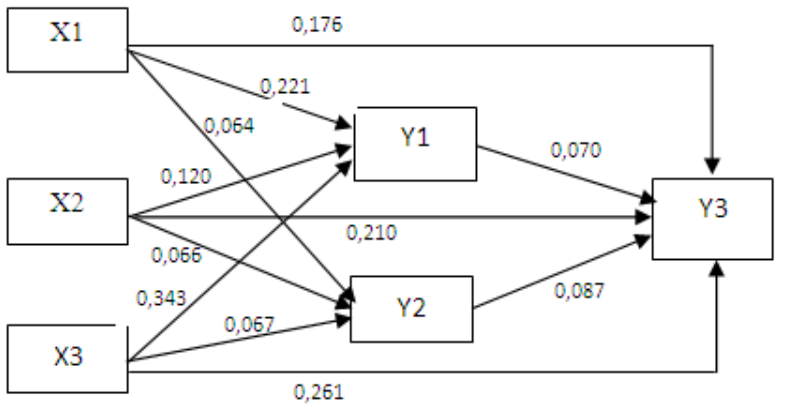

Source: result processed by SPSS 21 (2015).

Fig. 3. Path diagram

- The influence of emotional marketing variable on customer loyalty through customer satisfaction IE: $\mathrm{X} 2 \rightarrow \mathrm{Y} 1 \rightarrow \mathrm{Y} 3=(0.120 \times 0.070)=0.00840$

- The influence of spiritual marketing variable on customer loyalty through customer satisfaction IE $: \mathrm{X} 3 \rightarrow \mathrm{Y} 1 \rightarrow \mathrm{Y} 3=(0.343 \times 0.070)=0.02401$

- The influence of rational marketing variable on customer loyalty through customer trust

IE: $\mathrm{X} 1 \rightarrow \mathrm{Y} 2 \rightarrow \mathrm{Y} 3=(0.064 \times 0.087)=0.005568$

- The influence of emotional marketing variable on customer loyalty through customer trust

IE: $\mathrm{X} 2 \rightarrow \mathrm{Y} 2 \rightarrow \mathrm{Y} 3=(0.066 \times 0.087)=0.005742$

- The influence of spiritual marketing variable on customer loyalty through customer trust

IE: $\mathrm{X} 3 \rightarrow \mathrm{Y} 2 \rightarrow \mathrm{Y} 3=(0.067 \times 0.087)=0.005829$

6.2.2. The influence of rational factor on customer satisfaction. From the result of the partial test, it was discovered that rational factor had positive and insignificant influence on customer satisfaction. Rational marketing assumes human as a logical creature will choose products based on rational considerations, such as price or product quality. In this study, customers thought that administrative fees and profit sharing implemented by Bank Sumut Shariah were similar to interests implemented by conventional banks. It's reflected in respondents' answers. The result showed that rational marketing wasn't a consideration to become customers of Bank Sumut Shariah.

6.2.3. The influence of emotional factor on customer satisfaction. From the result of partial test, it was discovered that emotional factor had a positive and significant influence on customer satisfaction. Emotional marketing is related to human feelings or emotions. Purchases based on emotional motivations are based on subjective or personal reasons. Customers also selected Bank Sumut Shariah, because they had been customers of conventional bank Sumut because of the satisfaction and trust experienced from conventional bank Sumut. It's consistent with Kartajaya's (2004, p. 14) statement that emotional marketing is a marketing strategy designed based on consumers' desire to buy to express their emotions and feelings.
6.2.4. The influence of spiritual factor on customer satisfaction. From the result of partial test, it was discovered that spiritual factor had a positive and significant influence on customer satisfaction. In this study, customers were satisfied with the distribution system of Bank Sumut Shariah, which is consistent with Shariah, prioritizes ethics and honesty. It's considered prioritizing ethics, because the amount received by customers depends on the amount of profit received by the bank, so Bank Sumut Shariah was considered more fair than the interest system in conventional banks. Bank Sumut Shariah is also transparent in calculating profit sharing, so it was considered honest. Respondents were also satisfied with Bank Sumut Shariah, because it does not misuse customers' funds and only invests customers' funds in halal fields. This is consisted with Mussry et al. (2007, p. 18) who state that spiritual marketing is a marketing strategy designed by ethics and honesty.

6.2.5. The influence of satisfaction on customer loyalty. From the result of partial test, it was discovered that satisfaction had a positive and significant influence on customer loyalty. Satisfaction is a level of feelings where one makes the comparison of the performances of products (services) received and expected. Customer satisfaction is experienced after consumers make post-purchase evaluation, where perceptions of the alternative performances of selected products/services meet or exceed pre-purchase expectations (Kotler and Keller, 2009). Satisfaction is customers' responses on the fulfillment of needs. It means assessment of the uniqueness of a product or service, which provides comfort related to the fulfillment of a need, including needs below expectations or fulfilling needs above customers' expectations. In this study, customers of Bank Sumut Shariah were satisfied with the Shariah system applied by Bank Sumut Shariah such as in the amount of profit sharing and the profit sharing system, transparence in calculating profit sharing and safety provided by Bank Sumut Shariah. Satisfaction and trust to what received the customers from Bank Sumut Shariah made them loyal and they didn't have to select other banks and were willing to recommend Bank Sumut Shariah to other people.

\section{Conclusion}

- Rational marketing had significant a positive influence on the satisfaction of Shariah banking customers in Medan.

- Emotional marketing had an insignificant influence on the satisfaction of Shariah banking customers in Medan.

- Spiritual marketing had a significant positive influence on the satisfaction of Shariah banking customers in Medan.

- Rational marketing had a significant positive influence on the satisfaction of Shariah banking customers in Medan. 
- Emotional marketing had a significant positive influence on the trust of Shariah banking customers in Medan.

- Spiritual marketing had a significant positive influence on the trust of Shariah banking customers in Medan.

- Rational marketing had a significant positive influence on the loyalty of Shariah banking customers in Medan.

- Emotional marketing had a significant positive influence on the loyalty of Shariah banking customers in Medan.

- Spiritual marketing had a significant positive influence on the loyalty of Shariah banking customers in Medan.

- Customer satisfaction had a significant positive influence on the loyalty of Shariah banking customers in Medan.

- Customer trust had a significant positive influence on the loyalty of Shariah banking customers in Medan.

\section{Limitation}

This study was limited to rational, emotional, spiritual marketing variables on satisfaction, trust, and loyalty of Shariah banking customers. Other variables, which influence satisfaction, trust, and loyalty such as customer relationship management (CRM) and portfolio performance, should be used because they're factors, which influence consumer behaviors.

\section{Suggestion}

Future researches on satisfaction, trust, and loyalty can use customer relationship management (CRM) and portfolio performance variables, which are factors influencing consumer behaviors. Good relation with customers is one of the key in developing satisfaction, trust, and loyalty.

\section{Research contribution}

The research result was the development of rational, emotional, and spiritual marketing strategy models, which was expected to benefit Shariah banking in Medan, so they can play their role in serving the public in providing Shariah banking products.

For Shariah banking in Medan, the research result was expected to give useful suggestions and inputs for Shariah banking in Medan in implementing marketing strategies, especially rational, emotional, and spiritual.

For future researchers, it should be a reference in conducting similar researches in the future.

\section{References}

1. Barnes, James G. (2003). Secrets of Customer Relationship Management. Translator by Andreas Winardi, Yogyakarta: Andi Publisher.

2. Dalimunthe, D. M. J., Fadli, and Muda, I. (2016). The application of performance measurement system model using Malcolm Baldrige Model (MBM) to support Civil State Apparatus Law (ASN) number 5 of 2014 in Indonesia. International Journal of Applied Business and Economic Research, 14(11), 7397-7407.

3. Dewanti, Retno, Tjia Fie Chu, and Wibisono, Steven. (2016). The influence of experiential marketing, emotional Branding, brand trust towards brand loyalty. Binus Business Review, 2(2), 1109-1117.

4. DeWitt, Tom, Doan T. Nguyen, and Marshall, Roger. (2008). Exploring Customer Loyalty Following Service Recovery The Mediating Effects of Trust and Emotions. Journal of Service Research, 10(3), 269-281

5. Griffin, Jill. (2002). Customer Loyalty How to Earn it, How to Keep It. Kentucky: Mc Graw Hill.

6. Lutfi, M., Nazwar, C., and Muda, I. (2016). Effects of investment opportunity set, company size and real activity manipulation of issuers in Indonesia Stock Exchange on stock price in Indonesia. International Journal of Economic Research, 13(5), 2149-2161.

7. Mussry, Jack, Michael, H, Taufik, Y. H., Paul, P., Suryo, S., and Alexander, M. (2007). Markplus on Marketing, The second Generation. Jakarta: Ikrar Mandiri Abadi.

8. Muda, I., and Dharsuky, Abykusno. (2015). Impact Of Region Financial Information System (SIKD) Quality, Role Ambiguity And Training on Precision of Financial Statement of Local Government Presentation In North Sumatra. International Journal of Applied Business and Economic Research, 13(6), 4283-4304.

9. Muda, I., Dharsuky, A., Sadalia, I., and Siregar, H. S. (2016). Impact of capital investments and cash dividend policy on Regional Development Bank (BPD) PT. Bank Sumut to the district own source revenue and economic growth. International Journal of Applied Business and Economic Research, 14(11), 7863-7880.

10. Kartajaya, Hermawan. (2003). Marketing in Venus. Jakarta: SUN Publishers.

11. Kartajaya, Hermawan. (2004). Marketing 3.01. Jakarta: SUN Publishers.

12. Livingston, Glenn. (2016). Emotion vs emotional Benefit in Marketing. Retrieved March, 12, 2016, from http://tlgonline.com/sharon/ articles/030516.asp

13. Kotler, Philip, and Gary Armstrong. (2012). Principles of Marketing. New Jersey: Prentice Hall International, Inc.

14. Kotler, Philip, and Kevin Lane Keller. (2009). Marketing Management. 13 Edition, Jakarta: Erlangga Publishers.

15. Peppers, Don, and Martha Rogers. (2004). Managing Customer Relationship: A Strategic Framework. New Jersey; John Wiley \& Sons, Inc.

16. Rini, Endang Sulistya. (2007). Effect of Economic Content, Content Resource and Social Content of the Trust, Satisfaction and Commitment and Relationship Intention Debtor Bank in North Sumatra North Sumatra. Dissertation. University of Airlangga, Surabaya. 
17. Rini, Endang Sulistya, and Yeni, Absah. (2015). Analysis Creation Through Customer Loyalty Effect Marketing Strategies Rational, Emotional and Spiritual towards Customer Satisfaction PT. Bank Islamic North Sumatra Medan Main Branch. Journal of Management Studies and Business, 2(1), 63-76.

18. Tjiptono, Fandy. (2004). Marketing Management. Yogyakarta: Andi Publishers.

19. Waringin, Tung Desem. (2012). Sinergy between rational, emotional and spiritual marketing. Retrieved February, 20, 2015, from http://economy.okezone.com/read/2011/04/03

20. Zachra P. B., Ellyzar. (2011). Reach Consumers with Emotional Intimacy. Retrieved February, 20, 2015, from www.swa.co.id

21. Zeithaml, Valerie A., A. Parasuraman, and Leonard L. Berry. (1990). Delivering Quality Service (Balancing Customer Perception and Expectations). New York: The Free Press Division of MacMillan. 